\title{
Presence of Panstrongylus rufotuberculatus (Champion, 1899) (Hemiptera: Reduviidae: Triatominae) in Argentina
}

\author{
Oscar D Salomón/ ${ }^{+}$, Carlos M Ripoll*, Eduardo Rivetti*, \\ Rodolfo U Carcavallo**
}

\begin{abstract}
Centro Nacional de Diagnóstico e Investigación de Endemo-Epidemias (CeNDIE), Av. Paseo Colón 568, 1063,
Buenos Aires, Argentina *Departamento de Chagas y Patología Regional MBS, San Martín 41, 4600,

San Salvador de Jujuy, Argentina **Departamento de Entomologia, Instituto Oswaldo Cruz, Av. Brasil 4365,

21045-900 Rio de Janeiro, RJ, Brasil
\end{abstract}

Panstrongylus rufotuberculatus is reported for the first time in Argentina. Four adults were attracted by the light of human dwellings in Calilegua National Park, Jujuy, at 1150 masl within the subtropical humid forest. The individuals were similar to those described in the literature. The epidemiological significance of this species is very low in the area, although deforestation might increase its role in the transmission of Trypanosoma cruzi.

Key words: Panstrongylus rufotuberculatus -Triatominae - Argentina

The triatomines Panstrongylus megistus (Burmeister), 1835, P. guentheri Berg, 1879 and P. geniculatus (Latreille,1811) are the only species of the genus Panstrongylus Berg, 1879 previously reported from Argentina. Panstrongylus rufotuberculatus (Champion, 1899) is already known from Mexico, Costa Rica, Panama, Colombia, Venezuela, Brazil, Ecuador, Peru and Bolivia (Lent \& Wygodzinsky 1979, Zeledón \& Rabinovich 1981). The capture of $P$. rufotuberculatus in Calilegua National Park, Jujuy, is the first report of this species in Argentina and this collection extends the known species distribution, as this triatomine had never been reported south of Chapare province, Cochabamba department, Bolivia (18³0'S). In this paper the individuals found in Jujuy were compared to those preserved in collections and to the descriptions from the literature. The epidemiological potential of this species as a vector of Trypanosoma cruzi in Argentina and the variability of the species is also discussed.

\section{MATERIALS AND METHODS}

Specimens of $P$. rufotuberculatus were collected in the "Mesada Las Colmenas" Sector, Calilegua National Park, Province of Jujuy (2341'33"S, 6451'27"W, 1150 masl). The collecting site is surrounded by mountain forest. Two

\footnotetext{
${ }^{+}$Corresponding author and member of "Carrera del Investigador Científico" CONICET. Fax: 54-11-43312536. E-mail: daniel@inscha.gov.ar

Received 11 May 1998

Accepted 1 February 1999
}

individuals, a male and a female, were attracted by light to the exterior wall of the house of the park ranger on 23 October 1997.

The specimens were kept in $70 \%$ alcohol until they could be compared with the re-descriptions made by Lent and Wygodzinsky (1979), and Lent et al. (1998). A caliper $(0.01 \mathrm{~mm})$ was used and measurements made using an ocular micrometer.

A third individual was compared with the collection from different countries deposited in the collections of Lent and of Carcavallo at the Oswaldo Cruz Institute, Rio de Janeiro (IOC Collection).

\section{RESULTS}

Three species of the genus Panstrongylus Berg, 1879 were reported for Argentina: P. guentheri Berg, 1879, P. geniculatus (Latreille, 1811) and $P$. megistus (Burmeister, 1835). P. rufotuberculatus (Champion, 1899) differs from the two former species because it has the posterior process of the scutellum short and rounded, the anterior lobe of the pronotum with well developed antero-lateral and discal tubercles and distinct pattern of coloration. P. megistus also has the tubercles described but their color pattern is different (black connexivum, with a slender red posterior spot in each segment, the overall color being red spotted black or red spotted dark brown, very contrasting with the pronotum). The jugae of $P$. megistus have hook-like projections while in $P$. rufotuberculatus these are blunt. The species described by Champion is very variable, the connexivum being yellow, orange or reddish, with a rectangular central spot in each segment, slightly biconcave, and with a thin black band close to the intersegmental su- 
ture. The overall body color is yellowish-green (unusual among triatomines), and the pronotum, hemielytra, legs and head are patterned with brown, gray, black or reddish. The green color is lost after a couple of years in dried specimens and in individuals exposed to chemical preservatives such as alcohol, ether and formalin.

The specimens collected at Calilegua correspond fairly well with the re-description by Lent and Wygodzinsky (1979), and the measurements recorded by Lent et al. (1998). The variability in chromatic, morphologic and morphometric characters were remarked on by the former authors. The overall length of $P$. rufotuberculatus varies greatly, even among individuals of different parts of the same country; thus individuals from Monagas State in Venezuela measured $28 \mathrm{~mm}$, while those of Cojedes State, measured only 17 $\mathrm{mm}$ (IOC Collection). Thus, the comparison reported in the Table is compatible with the intraspecific variability of a very variable species. The ratio widht of eye to synthlipsis, and the shape of the setae of the Argentinian insects were closer to those from Panama (Barro Colorado) than to those from Peru (Convencion Valley, Cuzco Dept.) depicted and detailed by Lent and Wygodzinsky (1979). However, the carinae limiting the central depression of the scutellum is similar to specimens from Costa Rica, Venezuela, Peru, Bolivia and Brazil (entire black scutellum) but with a different pattern from the Panama and Colombia insects (red or reddish carinae).

According to Lent and Wygodzinsky (1979): "The variability described seems to be geographical in nature". To support this hypothesis the variability found among the individuals from the same site is usually narrower than that of populations from different countries. The single $P$. rufotuberculatus from Calilegua compared with those deposited at the IOC shares many characters with the specimens from Bolivia (Nor Yungas and Chapare), and with four specimens recently collected from Costa Rica between 100 and 1500 masl (R Zeledón leg.).

\section{DISCUSSION}

The presence of $P$. rufotuberculatus in Calilegua (within the subtropical humid forest) at 1150 masl is consistent with the habitat preference of these specimens reported in the literature. Is also consistent with the fact that the "Las Yungas" humid subtropical forest of Bolivia, where $P$. rufotuberculatus was reported, and the "TucumanOranense" forest of Argentina are contiguous. The first collections of $P$. rufotuberculatus in Bolivia (Prosen \& Martínez 1951) were followed by other

TABLE

Comparisons between the specimens of Pastrongylus rufotuberculatus re-described by Lent and Wygodzinsky (1979) (LW) and those found in Calilegua, Argentina

\begin{tabular}{lll}
\hline Character & LW & Calilegua \\
\hline Male length & $24-27 \mathrm{~mm}$ & $23.31 \mathrm{~mm}$ \\
Female length & $25-28 \mathrm{~mm}$ & $23.95 \mathrm{~mm}$ \\
Pronotum width & $6-7 \mathrm{~mm}$ & $6.06-6.11 \mathrm{~mm}$ \\
Male abdomen width & $8-9 \mathrm{~mm}$ & $8.04 \mathrm{~mm}$ \\
Female abdomen width & $9-10 \mathrm{~mm}$ & $8.98 \mathrm{~mm}$ \\
Dorsal setae & Different shapes & Like Panama example \\
Head length: width & $1: 0.65-0.80$ & $1: 0.73-0.74$ \\
Head: Pronotum length & $1: 1.15-1.45$ & $1: 1.14-1.23$ \\
Anteocular: postocular length & $1: 0.25-0.35$ & $1: 0.21-0.24$ \\
Apex of clypeus & Uni or bilobed & Unilobed \\
Eye width: synthlipsis & $1: 1.30-1.85$ & $1: 1.88-1.94$ \\
& $1: 2.3-3.3^{a}$ & \\
Antennae first article & Slightly surpassing clypeus & Not surpassing apex of clypeus \\
Antennal articles & $1: 3.0-3.5: 2.2-2.8: 1.9-2.3$ & $1: 2.8-3.1: 2.3-2.4: 1.9-2.0$ \\
Rostrum articles & $1: 1.9-2.2: 0.6-0.7$ & $1: 2.4: 0.8$ \\
Pronotum color & Dark brown to black & Black \\
Humeral angle & Narrowly rounded to subangular & Subangular \\
Scutellum posterior process & Apically or enterely red & Enterely red \\
Scutellum central carinae & Red or black & Black \\
Scutellum apex & Rounded, suboval or subglobose & Suboval \\
Fore femora width: length & $1: 3.8-4.7$ & $1: 3.8-4.0$ \\
Connexivum pattern: transversal & Connected or not along outer & Not connected \\
band-median spot & &
\end{tabular}

$a$ : specimens from Cuzco, Peru. 
captures by the same authors (material in several collections), by Torrico (1958) and the collections of Martínez in 1977, which Carcavallo and Martínez (1985) dissected for parasites. Interestingly Noireau et al. (1994) found adults inside houses from the Oriental Mountains (2600 masl) and in Nor Yungas (1500 masl). Furthermore, in the latter site they also collected four nymphs inside houses, which may suggest the beginning of a domicile colonization. In Colombia P. rufotuberculatus was found at elevations from 650 to 1100 masl, from the humid tropical forest of the Pacific to the xerophytic forest of the Cauca valley (D'Alessandro \& Barreto 1985). In Ecuador $P$. rufotuberculatus was found at 5 and 1066 masl in the coastal provinces of Manabi and Guayas as well as at the humid tropical Andean valleys (Lazo 1985). In Peru this species was collected between 1200 and 1900 masl in the high forest of Cuzco and the northern departments of Tumbes and Piura (Calderón et al. 1985), while in Costa Rica this species also occurs in the humid forest. In Mexico, the insects were attracted by light (Zárate \& Zárate 1985) in humid forests of Lacandona, Chiapas state and Los Tuxtlas, Veracruz state.

$P$. rufotuberculatus has been found naturally infected with T. cruzi on several occasions since the first report from Venezuela (Lent \& Pífano 1940). Infected specimens were reported from Panama (Sousa 1972, Sousa et al. 1983) and Santa Cruz, Bolivia (Carcavallo \& Martínez 1985, insects collected by Martínez and studied by these authors in 1977). A natural infection rate of $14.2 \%$ (León \& León 1953, Lazo 1985) was found on $P$. rufotuberculatus from the coastal province of $\mathrm{El}$ Oro, Ecuador.

The relationship between $P$. rufotuberculatus and potential mammalian hosts of $T$. cruzi was studied by different researchers. Rodríguez and Melo (1942) found this triatomine associated with the kinkajou Potos flavus, D'Alessandro et al. (1981) found it in relation with the Desmodus rotundus bat in Colombia, and Miles (1979) found it associated with armadillos in the Brazilian Amazon. All these mammals have been found naturally infected with T. cruzi (Barreto 1985).

P. rufotuberculatus has been described as a typical sylvatic species that is occasionally attracted by the light of houses surrounded by forest (Lent \& Wygodzinsky 1979), as found in the present study. In Bolivia, Borda Pisterna (1985) dismissed any epidemiological role for this species, although Noireau et al. (1994) think that it does have a tendency to colonize houses. In Ecuador the "semidomestic" individuals collected were adapted to the rural mud and cane houses of Loja and El Oro provinces (Zeledón \& Rabinovich 1981, Lazo
1985). The domestication of $P$. rufotuberculatus was also reported in Peru (Calderón et al. 1985), where $38 \%$ of 172 mud-mantled houses surveyed in Cuzco Dept. in 1980 were found to be infested. This may be due to the intense deforestation - immediate colonization process (cocoa, coffee, fruit trees plantations) that occurs in the area.

According to biometric and comparative observations with individuals collected in other places, and based on the literature available, we conclude that the specimens from Calilegua (Jujuy) are consistent with the intraspecific variability of $P$. rufotuberculatus. Another two adults of $P$. rufotuberculatus were collected in the same place in February, 1996, as reported to the National Service of Chagas in November of that year (Ripoll, pers. comm.).

The absence of previous reports of $P$. rufotuberculatus for Argentina may be due to: (a) lack of previous collections from the sampled area, (b) low population densities of this species, or (c) colonization of the area by $P$. rufotuberculatus may be relatively recent. The epidemiological potential of this species for T. cruzi transmission in Argentina may be reduced by the restricted localization of its populations, despite its broad continental distribution. However, a role for P. rufotuberculatus in the non-domestic cycle of $T$. cruzi should not be discarded. The mammal species that have been found naturally infected elsewhere are species and families of mammals found in Calilegua. The reports of domiciliation of $P$. rufotuberculatus following deforestation in Bolivia, Ecuador and Peru should also be taken into account, even in small areas.

\section{ACKNOWLEDGEMENTS}

To Mr Pablo Giorgis, Ranger of Calilegua National Park who made the captures, to Dr Mario Zaidenberg and Lic Liliana Ciotek (National Service of Chagas, Salta), and to Dr Nicolás Schewigmann (Buenos Aires University) for their collaboration.

\section{REFERENCES}

Barretto MP 1985. Reservorios de Trypanosoma (Schizotrypanum) cruzi Chagas - 1909, p. 275-288. In RU Carcavallo, JE Rabinovich \& RJ Tonn (eds), Factores Biológicos y Ecológicos en la Enfermedad de Chagas, OPS/ECO, MSAS/SNCh, Buenos Aires.

Borda Pisterna M 1985. Bolivia, p. 355-362. In RU Carcavallo, JE Rabinovich \& RJ Tonn (eds), Factores Biológicos y Ecológicos en la Enfermedad de Chagas, OPS/ECO, MSAS/SNCh, Buenos Aires.

Calderón GF, Figueroa Krap E, Naquira F 1985. Perú, p. 449-456. In RU Carcavallo, JE Rabinovich \& RJ Tonn (eds), Factores Biológicos y Ecológicos en la Enfermedad de Chagas, OPS/ECO, MSAS/SNCh, Buenos Aires.

Carcavallo RU, Martinez A 1985. Biología, ecología y 
distribución geográfica de los triatominos americanos (con excepción de $R$. prolixus, P. megistus, $T$. dimidiata y T. infestans), p. 149-208. Vol. I. In RU Carcavallo, JE Rabinovich \& RJ Tonn (eds), Factores Biológicos y Ecológicos en la Enfermedad de Chagas, OPS/ECO, MSAS/SNCh, Buenos Aires.

D’Alessandro A, Barreto P 1985. Colombia, p. 377-399. In RU Carcavallo, JE Rabinovich \& RJ Tonn (eds), Factores Biológicos y Ecológicos en la Enfermedad de Chagas, OPS/ECO, MSAS/SNCh, Buenos Aires.

D’Alessandro A, Barreto P, Thomas M 1981. Nuevos registros de triatominos domiciliarios y extradomiciliarios en Colombia. Colombia Med 12: 75-85.

Lazo RF 1985. Ecuador, p. 413-427. In RU Carcavallo, JE Rabinovich \& RJ Tonn (eds), Factores Biológicos y Ecológicos en la Enfermedad de Chagas, OPS/ ECO, MSAS/SNCh, Buenos Aires.

Lent H, Pifano F 1940. Sôbre a identidade dos gêneros Panstrongylus Berg, 1879 e Mestor Kirkaldy, 1904. Redescrição de Panstrongylus rufotuberculatus encontrado na Venezuela naturalmente infetado pelo Schyzotrypanum cruzi. Rev Entomol 11: 629-639.

Lent H, Wygodzinsky P 1979. Revision of the Triatominae (Hemiptera, Reduviidae), and their significance as vectors of Chagas' disease. Bull American Mus Nat Hist 163: 379-438.

Lent H, Carcavallo RU, Martínez A, Galíndez Girón I, Jurberg J, Galvão C, Canale DM 1998. Relationships and characterization of the species, Vol I, p. 245-264. In RU Carcavallo, I Galíndez Girón, J Jurberg \& H Lent (eds), Atlas of Chagas' Disease Vectors in the Americas, Fiocruz, Rio de Janeiro, Brazil.
León LA, León BC 1953. Transmisores naturales y experimentales del Trypanosoma cruzi en el Ecuador. Rev Ecuatoriana Entomol Parasitol 1: 45-62.

Miles MA 1979. Transmission cycles and heterogeneity of Trypanosoma cruzi, Vol 2, p. 117-196. In WHR Lumsden, DA Evans (eds), Biology of Kinetoplastida, Academic Press, London.

Noireau F, Bosseno MF, Vargas F, Brenière SF 1994. Apparent trend to domesticity observed in Panstrongylus rufotuberculatus Champion, 1899 (Hemiptera: Reduviidae) in Bolivia. Res Rev Parasitol 54: 263-264.

Prosen AF, Martínez A 1951. Algunas notas sobre triatómidos. Misión Est Pat Reg Argentina (MEPRA) 79: 59-65.

Rodrígues B, Melo GB 1942. Contribução ao estudo da tripanosomiase americana. Mem Inst Oswaldo Cruz 37: 79-90.

Sousa OE 1972. Anotaciones sobre la enfermedad de Chagas en Panamá. Frecuencia y distribución de Trypanosoma cruzi y Trypanosoma rangeli. Rev Biol Trop 29: 167-179.

Sousa OE, Wolda H, Batista LF 1983. Triatominos encontrados en el ambiente silvestre en la isla de Barro Colorado. Rev Med Panamá 8: 50-55.

Torrico RA 1958. Reconocimiento de nuevas áreas de distribución de triatominos en Bolivia. An Lab Central 4: 11-14.

Zárate LG, Zárate RJ 1985. A checklist of the triatominae (Hemiptera: Reduviidae) of Mexico. Intern $J$ Entomol 27: 102-127.

Zeledón R, Rabinovich JE 1981. Chagas' disease: an ecological appraisal with special emphasis on its insect vectors. Annu Rev Entomol 26: 101-133. 